
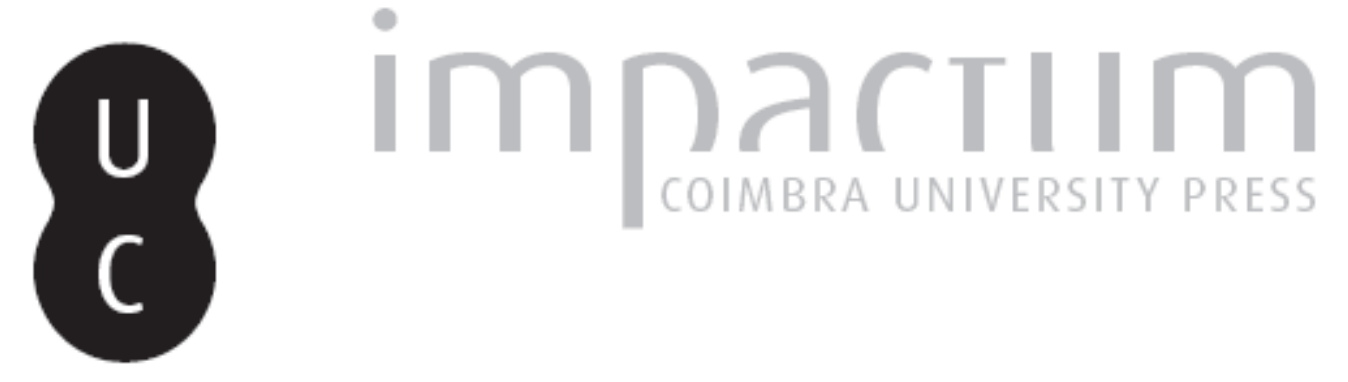

\title{
O ensino do jornalismo em tempos de mudança ou como a Universidade deve suplantar o Super-Homem
}

\author{
Autor(es): $\quad$ Figueira, João
}

Publicado por: Imprensa da Universidade de Coimbra

URL persistente:

URI:http://hdl.handle.net/10316.2/41219

DOI:

DOI:https://doi.org/10.14195/2183-6019_3_4

Accessed : $\quad$ 26-Apr-2023 14:11:32

A navegação consulta e descarregamento dos títulos inseridos nas Bibliotecas Digitais UC Digitalis, UC Pombalina e UC Impactum, pressupõem a aceitação plena e sem reservas dos Termos e Condições de Uso destas Bibliotecas Digitais, disponíveis em https://digitalis.uc.pt/pt-pt/termos.

Conforme exposto nos referidos Termos e Condições de Uso, o descarregamento de títulos de acesso restrito requer uma licença válida de autorização devendo o utilizador aceder ao(s) documento(s) a partir de um endereço de IP da instituição detentora da supramencionada licença.

Ao utilizador é apenas permitido o descarregamento para uso pessoal, pelo que o emprego do(s) título(s) descarregado(s) para outro fim, designadamente comercial, carece de autorização do respetivo autor ou editor da obra.

Na medida em que todas as obras da UC Digitalis se encontram protegidas pelo Código do Direito de Autor e Direitos Conexos e demais legislação aplicável, toda a cópia, parcial ou total, deste documento, nos casos em que é legalmente admitida, deverá conter ou fazer-se acompanhar por este aviso.

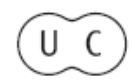


revista de comunicação,

jornalismo e espaço público

3

Periodicidade

Semestral

Imprensa da Universidade de Coimbra

Coimbra University Press

\section{mediapolis}

tema

o ensino do jornalismo

no século XXI

$\underline{ }$ 







\section{O ensino do jornalismo em tempos de mudança ou como a Universidade deve suplantar o Super-Homem

Journalism teaching in times of change or how must the University supplant the Superman

Resumo

O presente artigo parte dos contextos em que o jornalismo é hoje exercido, com os seus dilemas e ambiguidades, para problematizar o ensino de uma prática profissional em mudança e em erosão. Como ensinar e credibilizar o ensino do jornalismo, se o seu exercício é tão fugidio? A resposta que aqui se procura dar vai no sentido de defender o papel da Universidade como referência na prática do jornalismo.

Palavras-Chave: Ensino, jornalismo, universidade, profissão, comunicação.
Abstract

This article aims to understand the contexts in which journalism is exercised nowadays, with their dilemmas and ambiguities, with the purpose of questioning the teaching of a professional practice which faces a changing and erosion process. How must we teach and make the journalism teaching into a credible and relevant university discipline, when its professional pratice is so problematic and elusive? The answer we are looking for is in order to defend the role of the University as a reference and enlighten the practice of journalism.

Keywords: Teaching, journalism, university, profession, communication. 


\section{Introdução}

Interpelar o que chamamos de realidade é querer ver o futuro a partir das perguntas que fazemos. Por exemplo: o que ensinar e como ensinar a ser jornalista, quando a profissão vive a sua maior transformação de sempre (Pavlik, 2014; Klatell, 2013; Anderson et al, 2013; Ramonet, 2012) e os critérios e princípios teóricos são diariamente desmentidos por uma prática veloz asfixiada pelas audiências e pelos resultados económicos? (Silverman, 2015; Nichols \& McChesney, 2013).

Pode pensar-se o ensino do jornalismo desligando-o dos contextos em que ele se realiza, sabendo-se que as condições do seu exercício são muito diversas e que os interesses dos públicos nem sempre coincidem com as opções editoriais? (Boczkowski \& Eugenia, 2013).

No contexto atual (Bell, 2014; Anderson et al 2013; Innerarity, 2010; Deuze, 2008), onde as dúvidas são mais que as certezas e escasseiam respostas definitivas e tranquilizadoras (Nichols \& McChesney, 2013; Varela, 2011; Picard, 2010; Kovach \& Rosenstiel, 2010), é difícil esperar do ensino do jornalismo um pensamento unívoco sobre a sua forma de atuar.

$\mathrm{O}$ presente artigo começa por observar as transformações operadas na profissão e os seus próprios dilemas e constrangimentos - por entender que é impossível pensar o ensino do jornalismo sem atender aos quadros dominantes e referenciais em que ele é exercido. Num segundo momento, defende que cabe à Universidade, num quadro de défice referencial da profissão, proporcionar um ensino do jornalismo interveniente, mais prático, mais exigente, atento às realidades mais próximas e sem depender da volatilidade dos mercados ou das audiências, mas capaz de mostrar como faz sentido e é possível aproximar os parâmetros teóricos que enformam a profissão, do seu exercício (Meditsch \& Frighetto, 2015).

Adiantam-se, por isso, algumas propostas de alteração ao atual figurino de ensino, para o tentar ajustar às mudanças de contexto e dar à sua prática em cenário universitário um perfil mais profissional e experimental. Consideramos que, se o quadro operativo da profissão muda, o seu ensino não pode deixar de mover-se também. Prosseguir sem desvios nem ajustamentos no caminho que nos trouxe até aqui é correr o risco de um dia estarmos no lugar da orquestra que toca enquanto o Titanic se afunda.

\section{Super-Homem desiste do jornalismo}

Em outubro de 2012 o Super-Homem abandonou o jornalismo para se tornar um Blogger, após quatro décadas de ligação ao Daily Planet ${ }^{1}$. Desiludido e triste com a crescente transformação da informação em entretenimento e com a aquisição do jornal por um conglomerado económico, cujos interesses já não coincidem com os valores da profissão, Clark Kent, alter-ego do homem voador e com músculos de aço, capitulou pela primeira vez ao assumir ser incapaz de continuar a viver numa redação onde os repórteres já são, sobretudo, estenógrafos e em que o espaço editorial passou a ser preferencialmente ocupado por opinião em detrimento da informação.

1 Em 1938, quando foi criada a personagem, trabalhava no Daily Star. 
Este desajustamento ficcional, construído pelo autor dos diálogo de Kent, Scott Lodbell, tem, infelizmente, uma ligação forte, umbilical, diria, com a realidade que os media hoje enfrentam. Daí que a mudança de atividade de Clark Kent para o campo dos Bloggers, território onde opinião e informação se misturam sem as preocupações deontológicas do jornalismo, foi olhada na altura como uma mudança normal e natural de emprego, como um sinal dos tempos.

Tempos difíceis e complexos, sem dúvida, ao ponto de terem motivado o vencedor do Prémio Revelação Gazeta de Jornalismo² 2014, Fábio Monteiro, a proclamar no momento em que recebeu a respetiva distinção, em dezembro de 2015, a seguinte observação: "Giras, leves, curtas e, como não podiam deixar de ser, sexys. Estes são alguns dos adjetivos utilizados hoje para descrever o que é uma boa

2 Os prémios Gazeta de Jornalismo, atribuídos anualmente pelo Clube de Jornalistas, são a mais importante distinção para trabalhos em todas as áreas do jornalismo. notícia, dentro de muitas, para não dizer todas, as redações" ${ }^{3}$.

Dois dias depois, no quadro dos anunciados despedimentos e alterações nos jornais $i$ e Sol, fruto da saída da estrutura acionista do grupo angolano Newshold, o crítico António Guerreiro escrevia na edição eletrónica do Público que "os jornalistas são hoje uma classe proletarizada a quem não é reconhecida a pertença ao universo profissional dos que gozam de autonomia intelectual"4. Como Clark Kent, que criticava o aumento da Opinião, em prejuízo do jornalismo que procura os acontecimentos e faz reportagem, António Guerreiro vai mais longe ao sustentar que se

as notícias, de um modo geral, deixaram de ser a matéria-prima dos jornais, o poder oligárquico transferiu-se em grande parte para a chamada 〈opinião〉», que

3 Declaração feita a 16/12/2015, quando da entrega do Prémio referido no texto. Acessível em: http://www.clubedejornalistas. $\mathrm{pt} / \mathrm{p}=11863$

4 Artigo publicado em 18/12/2015, sob o título, "Como se fosse um destino". Acessível em: http://www.publico.pt/culturaipsilon/ noticia/como-se-fosse-um-destino-1717573 se dilatou de maneira insensata e se tornou um derivado do entretenimento. E como a opinião pode ser fornecida por pessoas exteriores, no limite um jornal é apenas um novo género editorial, isto é, o produto de escolhas e decisões que não exigem a concepção de um jornal como uma totalidade. O jornalismo torna-se assim mais um ramo da <indústria de conteúdos'>, que é uma coisa que se dispensou de pensar a sua forma ${ }^{5}$.

Gabriel García Márquez, no discurso que proferiu, em 1996, na Sociedade Interamericana de Imprensa, sob o título, "A melhor profissão do mundo", já antecipava, de resto, o cenário que a primeira década e meia do século seguinte viria a confirmar: "no caso específico do jornalismo parece que a profissão não conseguiu evoluir na mesma velocidade que seus instrumentos, e os jornalistas se perderam no labirinto de uma tecnologia em disparada desenfreada para o futuro" (Márquez, 1996, p. 8).

5 Idem. 


\section{Mudanças de contexto} e novas turbulências

Com a tecnologia que acelerou todas as mudanças e com isso gerou um outro ecossistema mediático e comunicacional, veio uma nova economia a mostrar que o modelo de negócio em que o jornalismo se estruturou e desenvolveu desde finais do século XIX está claramente esgotado (Anderson, et al. 2013; McChesney \& Nichols, 2010), o que exige renovadas soluções e abordagens e implica, por extensão, uma análise e reflexão outras sobre o ensino do jornalismo (Meditsch \& Frighetto, 2015).

Por outro lado, observa-se a emergência de uma diversidade de conteúdos híbridos, cada vez mais visíveis nas televisões dedicadas à informação, como são os casos, em Portugal, de programas como "Sucesso.pt", "Imagens de marca" (SIC-Notícias) ou ainda "RTP running" (RTP3) ${ }^{6}$, onde não existe qualquer fronteira entre o que deve ser o trabalho jornalístico,

6 Os créditos finais confirmam que os conteúdos são produzidos pela Associação Portuguesa dos Industriais de Calçado, Componentes, Artigos de Pele e Seus Sucedâneos (APICCAPS). distanciado de interesses comerciais, e a promoção pura e simples de produtos e consumos, que nos é dada sob o formato de notícias, entrevistas e reportagens jornalísticas (Figueira, 2015, p. 70).

É neste contexto que entendemos as estimulantes reflexões de Marshall, especialmente quando considera que "a lógica de mercado parece estar provocando uma transformação generalizada dos padrões éticos, estéticos e culturais do universo da informação, reduzindo aparentemente o jornalismo a uma simples esfera de sustentação para interesses puramente comerciais" (Marshall, 2003, p. 24). $\mathrm{Ou}$ ainda, quando, de forma mais severa, afirma que

\footnotetext{
"a notícia que jorra hoje nos noticiários de $T V$, rádio, jornal ou internet, em todo o globo, apresenta-se apenas como uma casca. A informação não é ativa, não possui as causas e os porquês, não é incendiária nem mobilizadora. Como uma mercadoria, ela não tem o objetivo de despertar o sujeito e, mesmo que mostre os sinais de corrosão do sistema, não distribui
}

Observa-se a

emergência de uma

diversidade de

conteridos híbridos,

cada vez mais visúveis

nas televisões

dedicadas à

informação 
os elementos necessários para a cristalização de uma opinião crítica e contestadora" (Marshall, 2003, p. 37).

Um estudo publicado em 2011 pela Comissão Federal de Comunicação dos Estados Unidos reafirma, por outras palavras, o mesmo sentido de alerta que encontramos nas palavras de Marshall, quando refere que o jornalismo está em risco, porque o seu exercício, segundo os princípios da independência e da velha função do "watchdog" já não existem. Em Dollarocracy, Nichols \& McChesney (2013) reforçam as mesmas preocupações e chamadas de atenção. Os dois investigadores concluem que a informação jornalística vive sob a influência e domínio dos profissionais de Relações Públicas e das suas mensagens manufaturadas, destinadas aos espaços noticiosos. Por todas estas razões entendem que "pode não haver muito jornalismo, mas há seguramente muitas «notícias»" (Nichols \& McChesney, 2013, p. 194).

Perante estes tempos de mudança, a professora da Universidade de Brasília, Thais de Mendonça Jorge, propõe uma abordagem que, tendo por referencial teórico as notícias como construção, defende uma aproximação do conceito de Genética ao estudo do jornalismo. Apoiando-se na perspetiva de Pierre Lévy, para quem a Humanidade enfrenta uma mutação que toca as diferentes áreas da vida humana, com implicações fortes e profundas no modo como as pessoas se relacionam e comunicam, a investigadora brasileira extrai a ideia de que "a notícia é um dos elementos da transformação cultural que está ocorrendo" (Jorge, 2013, p. 12).

No quadro das mudanças que vimos observando, Jorge (2013, p.18) releva, sobretudo, os processos de construção da notícia e menos os seus contextos organizacionais. Em todo o caso é muito relevante o contributo que dá para o enriquecimento do debate e das abordagens sobre as mutações e transformações do jornalismo. Nessa medida, e prosseguindo no olhar comparado com a Genética, sustenta que "o DNA da notícia são os factos; e o modo de colhê-los, processá-los, apresentá-los, é que muda".

À semelhança de Pavlik (2014), Singer (2013) ou Krotz (2007) que vêm o jornalismo como uma atividade já não exclusiva dos jornalistas - e onde a ideia de possibilidade comunicacional suplanta a noção de informação jornalística - e em que a utilização de novas plataformas, incluindo as redes sociais, afetam (ou influenciam) os processos de produção noticiosa e a sua circulação, Jorge (2013, pp. 6768) admite também a participação dos leitores neste novo circuito marcado justamente pela possibilidade da interação. Trata-se, no fundo, da confirmação de um postulado introduzido em 2006 por Jay Rosen e que ficou célebre: "the people formerly known as the audience" .

Em todo o caso, e não obstante, entender a notícia como "um organismo vivo, pulsante", a mesma investigadora considera que ela é "feita tradicionalmente por jornalistas" (...) "que não se metamorfoseia, mas muda junto com os jornalistas, o ambiente e a cultura em que está inserida" (Jorge, 2013, p. 258).

$7 \quad$ O professorJay Rosen mantém há vários anos um blog - Pressthink - onde apresenta e debate os mais diversos temas sobre jornalismo, designadamente sobre o futuro da imprensa na era digital e os desafios que tal mudança implica, assim como discute o papel e função do jornalismo nas sociedades atuais. Acessível em: http://archive. pressthink.org/2006/06/27/ppl_frmr.html 
Assim sendo, defende que "as mudanças na notícia não acontecem sem transformações no processo cognitivo: muda quem faz (os jornalistas), muda o que é feito (o conteúdo da notícia, ou seja, o conhecimento) e muda quem consome (os leitores)" (Jorge, 2013, p. 17).

Existem, no entanto, outras mudanças importantes a que importa atender e que, de forma muito resumida, circunscreveríamos aos processos de colheita, produção e distribuição da informação noticiosa. Do nosso ponto de vista é aqui que está situado o epicentro de toda a turbulência que o jornalismo sente e sofre e que sintetizamos em cinco pontos:

1) os media noticiosos perderam o monopólio que detiveram durante um século ao nível da produção e distribuição de informação a larga escala, além de que os cidadãos já não dependem deles para saber de notícias em primeira mão;

2) hoje já não é em função da informação jornalística que são tomadas as principais decisões ao nível da gestão das empresas de media;

3) as redações dispõem crescentemente de menores recursos humanos;
4) existem outras áreas (e empresas) de comunicação que assumem formas e estruturas narrativas até há pouco exclusivas do jornalismo;

5) a crise no modelo de negócio dos media (que viram escapar os seus proventos publicitários para as grande plataformas e redes sociais), a que acresce um sentimento de indiferença por parte dos cidadãos, face a este fenómeno (Figueira, 2015, p. 74).

É este novo ecossistema mediático, onde "um novo jornalismo de declaração está a esmagar o velho jornalismo de verificação" (Kovach \& Rosenstiel, 2004 , p. 47) que entristece o jovem Fábio Monteiro, ciente de que "o último vencedor [do mesmo Prémio Revelação] que conseguiu ficar a trabalhar a tempo inteiro, em Portugal, foi o de 2008"8.

\section{Mais do que uma crise dos media?}

O problema, infelizmente, está longe de ser exclusivamente português,

8 Declaração feita a 16/12/2015, quando da entrega do Prémio referido no texto. Acessível em: http://www.clubedejornalistas. $\mathrm{pt} / \mathrm{p}=11863$. como sumariamente procuramos mostrar. O ano de 2016 começou, aliás, com o histórico diário La Presse de Montreal, fundado em 1884 e líder da imprensa francófona do Canadá, a deixar o seu território natural em papel, para aderir à versão digital. Apenas aos sábados - por enquanto - o velho jornal volta às rotativas para chegar aos quiosques e cafés da sua cidade. Nos outros seis dias, quem o quiser encontrar e ler tem de o procurar através da Net. Na última semana de março de 2016, o diário britânico The Independent (assim como a sua edição de domingo The Independent on Sunday) abandonaram a edição em papel, para se manter exclusivamente como plataforma online. Nesta, como na generalidade das situações, o que está em causa é o modelo de negócio dos media (Anderson et al, 2013), cujas empresas têm de procurar novas soluções e estratégias, sob pena de soçobrarem, por desadequação, face ao novo quadro em que o setor se move.

Jim Macnamara (2014), investigador e professor na Universidade de Sydney Oeste, interpela-se, a este respeito, acerca do futuro do jornalismo como o conhecemos, para concluir, como antes o fizera Eugenia Siapera, que ele 
Tão (ou mais)

\section{importante como}

saber como ensinar

\section{e o que ensinar}

nas escolas de

Jornalismo, seja

tentar perceber,

primeiro, porque

é que ainda há

tantos estudantes a

matricularem-se

num curso, cuja

principal profissão

de destino ou de

referência enfrenta

uma crise enorme próprio cita, que é impossível as sociedades contemporâneas suportarem, ou seja, viabilizarem, um modelo de jornalismo ultrapassado e irrelevante para o quotidiano dos seus cidadãos.

Perante este cenário, consideramos que tão (ou mais) importante como saber como ensinar e o que ensinar nas escolas de Jornalismo, seja tentar perceber, primeiro, porque é que ainda há tantos estudantes a matricularem-se num curso, cuja principal profissão de destino ou de referência enfrenta uma crise enorme, visível no encerramento de órgãos de comunicação, nos despedimentos constantes, nas suas más remunerações e, em muitos casos, com salários em atraso.

Dados revelados em dezembro de 2015 pelo European Journalism Observatory, citando a Comissão da Carteira Profissional de Jornalista, referem que Portugal perdeu 1218 jornalistas entre 2007 e o final de 2014, período em que o número de carteiras profissionais ativas baixou de 6839 para 5621 , o que corresponde a um decréscimo de $17,8 \%{ }^{9}$. Ao invés

\footnotetext{
9 A precariedade e o desemprego nas redações são tema central do artigo, disponível em: http:// pt.ejo.ch/jornalismo/portugal-perde-1218-
}

do que é frequente afirmar-se, os números refletem, a nosso ver, sobretudo uma crise das organizações jornalísticas e do seu modelo de negócio (com impacto evidente no despedimento de jornalistas) e não do jornalismo, uma vez este continuar, embora por outros meios e com outras formas de organização, a produzir notícias e a distribuir informação, desejavelmente adaptado aos novos contextos.

No extenso relatório produzido para o Tow Centre for digital journalism da Columbia Journalism School, intitulado, "Jornalismo pós-industrial: adaptação aos novos tempos", o grupo de estudo conclui que

\begin{abstract}
o que une gente digitalmente empreendedora de organizações tradicionais - Anjali Mullany, ex-

-Daily News; John Keefe, da rádio WNYC; Gabriel Dance, da sucursal do The Guardian nos Estados Unidos - e meios que já nasceram digitais, como WyoFile, Technically Philly e Poligraft, é o facto de organizarem suas premissas e
\end{abstract}

jornalistas-em-7-anos?utm_source=hoje.li\& utm_medium $=$ referral\&utm_campaign $=\mathrm{e}-$ mail. Consultado em 4/1/2016. 
processos em torno daquilo que agora é possível, como incluir interatividade em gráficos, dar ao público acesso direto a bancos de dados, solicitar imagens e informação ao público ou distribuir uma matéria por redes sociais. Não há como saber se o Poligraft (aliás, nem se o Daily News) ainda existirá daqui a dez anos, mas a experimentação em curso nessas organizações é um exemplo do bom uso de novas ferramentas na busca de objetivos jornalísticos (Anderson, Bell \& Shirky, 2013, p. 38).

Em Portugal, no entanto, continua ainda a ser dominante a visão centrada nas grandes organizações, isto é, nos media tradicionais e seus modelos de organização ${ }^{10}$, o que explica a visão sempre preocupada face a cenários tão desoladores (face à ausência também de alternativas e de experiências

10 Referimo-nos à forma convencional de organização das empresas de media que, em Portugal, continuam a investir pouco no jornalismo multimédia e no data-journalism. De resto, tirando o caso do Observador, fundado em maio de 2014, não há outro exemplo de uma empresa nativa do digital. novas) como os revelados pela Comissão da Carteira Profissional de Jornalista.

Apesar disso, existem, em nosso entender, três grandes fatores que explicam ainda o interesse pelo estudo do jornalismo, mas cujas motivações não devem ser confundidas com um entusiasmo pelo exercício de uma profissão em nítido processo de erosão (Figueira, 2015). Tentaremos demonstrar a seguir que a razão principal desse interesse reside nas oportunidades que a nova paisagem comunicacional proporciona. $^{11}$

\section{Alunos de jornalismo descobrem outras saídas}

Do que antes dissemos ressaltam, desde logo, as consequências introduzidas pela revolução digital, que

11 Consideramos que é prioritário fazer um estudo alargado sobre as motivações dos estudantes e as suas expetativas e objetivos quando decidem matricular-se em Jornalismo. Assim como saber qual a perceção que têm, no momento dessa decisão, sobre o panorama jornalístico português. Por outro lado, importa saber também se todas as instituições se confrontam com o mesmo tipo de motivações, ou se estas têm em conta um conhecimento apriorístico das respetivas instituições, por parte dos estudantes. abanou não apenas o velho edifício do jornalismo, como introduziu e acelerou o desenvolvimento de novas possibilidade de comunicação a larga escala. Entre as alterações produzidas avulta a afirmação da comunicação institucional e organizacional, com uma autonomia e protagonismo sem precedentes.

$\mathrm{Na}$ atualidade, como bem assinala a este respeito Ignacio Ramonet (2012, p.243), "os governos comunicam, as empresas comunicam, possuem jornais, rádios, têm porta-vozes mediáticos, têm estruturas de imprensa e é cada vez mais difícil para nós não identificar estes elementos como parte formadora da comunicação".

A noção de jornalismo, enquanto tarefa profissional de seleção, interpretação, tratamento e difusão de matérias informativas como que se distancia, assim, do conceito de jornalista, uma vez este estar enquadrado por um conjunto de preceitos éticos e, sobretudo, deontológicos, que circunscrevem, em Portugal ${ }^{12}$, a sua prática

120 estatuto legal que enquadra o exercício profissional do jornalismo não é universal. Há países, como Portugal, onde estão interditas, em simultâneo, as práticas 
e, em particular, o acesso à respetiva carteira. (Este, aliás, é um debate que importa ter, dado que a nova realidade comunicacional exige, em nossa opinião, que se olhe para aqueles dois conceitos à luz dos atuais contextos da profissão e dos seus operadores.)

Podemos, ainda, juntar outro traço distintivo, como seja o de estabelecer uma diferenciação entre o que é um órgão de comunicação social convencional e um outro veículo que, embora produza informação e comunique com diversos públicos, não está registado, junto da Entidade Reguladora Para a Comunicação Social (ERC), de forma a poder assumir um estatuto semelhante. Não deixa, todavia, de ser um media e de utilizar no processamento dos respetivos conteúdos as estratégias narrativas que durante anos foram património exclusivo do jornalismo (Chaparro, 2001), porquanto o seu objetivo, como qualquer notícia,

do jornalismo e da assessoria, entre outras incompatibilidades oficialmente discriminadas. No Brasil, para dar apenas um exemplo, elas podem exercer-se sem qualquer restrição. Não deixa de ser curioso notar, aliás, no Brasil, a existência de alguns manuais de redação jornalística feitos por associações profissionais de Relações Públicas ou afins. entrevista ou reportagem (e os seus conteúdos são também assim designados) visam ter a máxima visibilidade e tocar os diferentes públicos a que se destinam.

Paralelamente, como desgostosamente afirmava o jovem Fábio Monteiro, aquando da entrega do prémio Revelação, os critérios jornalísticos movem-se agora noutras direções, valorizando aquilo a que Picard (2010), Neveu (2005), e Patterson (2003), embora com enfoques diversos - e em tempos diferentes, o que mostra como a questão, não sendo nova, não desapareceu - classificaram de soft news. Assim sendo, já não é apenas o velho jornal enquanto obra cultural, como o conceptualizou Otto Groth (2011), que está em causa, mas todo o edifício noticioso como o conhecemos e estudamos até há pouco tempo que deve ser questionado, como, de resto, propõe António Fidalgo (2004, p. 1) quando pergunta se não será "o jornalismo uma forma obsoleta de informar?".

Acresce, ainda, que o acesso ao espaço digital, através do qual hoje se processa a maioria dos fluxos comunicacionais levou à emergência e afirmação de outros modelos de jornalismo, com a consequente procura, por parte das empresas, de profissionais com competências jornalísticas, de que sobressai o "brand journalism" e o jornalismo virado para temáticas de lazer, moda, consumos e aventura, propriedade de grupos económicos ou de marcas, como a Red Bull ou a Burberry, as quais tiram o máximo proveito das potencialidades comunicativas das novas plataformas e, em especial, das redes sociais (Lloyd \& Toogood, 2015, pp. 105-106). Em Portugal, algumas grandes empresas e marcas aderiram já, também, à produção de vários conteúdos de "brand journalism", numa tendência que mostra sinais de querer continuar a subir.

Jovens licenciados em jornalismo e jornalistas desempregados encontram, assim, novas e até mais bem pagas oportunidades de emprego nas áreas da assessoria e das relações públicas, cuja ação influencia fortemente a ação e o trabalho dos media noticiosos (Macnamara, 2014, pp. 124-128). Neste contexto, um aluno de jornalismo, hoje, sabe e confia que as competências que pode adquirir ao longo da sua formação universitária lhe serão úteis no acesso e desempenho de 
outras funções e profissões em que a comunicação, a informação e, portanto, a produção de conteúdos nos mais diversos suportes está longe de servir unicamente ou em primeiro lugar a instância jornalística.

A assessoria, as relações públicas e a comunicação organizacional (englobando-se aqui as noções de instituição e de empresa) constituem, pois, saídas e caminhos tão aliciantes quanto possuidores de maior taxa de empregabilidade, a que os jovens licenciados ou com formação em jornalismo podem aspirar.

\section{Discrepância entre oferta e procura}

Por outro lado, a tendência homogeneizadora que se observa na generalidade dos media noticiosos, marcada por uma ansiedade que busca nas audiências e no polo comercial, segundo a expressão de Bourdieu, a sua legitimidade, ao mesmo tempo que se subvalorizam os aspetos éticos e deontológicos, tem conduzido o jornalismo para fora do seu habitat. $\mathrm{Ou}$ seja, a busca incessante pelo mercado e por soluções consideradas mais leves e apelativas - fruto também da maior oferta proporcionada pelas diversas plataformas, onde as redes sociais assumem um indiscutível protagonismo - tem, no fundo, contribuído para o aligeiramento do jornalismo que referimos anteriormente, em especial o de referência, que é, também, aquele que serve de estrela-guia nas universidades.

Contudo, mesmo quando tal despersonalização é travada, a monitorização dos fluxos das procuras temáticas, por parte dos públicos, revela que há uma discrepância entre os critérios que ditam as ofertas editoriais e os interesses de quem busca a informação (Boczkowski \& Mitchelstein, 2013). Um estudo de 2013 no âmbito do qual foram analisadas 50 mil notícias publicadas nas edições electrónicas de 20 meios de comunicação de referência de sete países (EUA, Espanha, Inglaterra e Argentina, entre outros) conclui que há um fosso evidente entre a lista dos temas mais publicados e os que são mais lidos. Os dois investigadores da universidade Northwestern de Chicago que levaram a efeito o estudo observaram que os assuntos de política internacional e nacional, Economia e Sociedade são os que mais atenção geram junto dos órgãos estudados: CNN, The Guardian, El País, Nación, por exemplo. Porém, os temais mais procurados dizem respeito a desporto, sexo, entretenimento e espetáculos (Boczkowski \& Mitchelstein, 2013).

Devem os editores e os seus órgãos ceder aos interesses dos públicos, privilegiando as suas preferências, ou devem continuar a dar destaque aos assuntos mais relevantes para a construção de uma cidadania consciente, sabendo que não é isso que os seus leitores mais procuram? Devem os media, como dizia Antero dos jornais do seu tempo, ser o espelho lisonjeiro do público ou o seu severo mestre?

\section{Crise ética e rumos novos}

Um comunicado do Conselho Deontológico do Sindicato dos Jornalistas $^{13}$ divulgado no final de dezembro de 2014 dá consistência aos maiores receios, quando considera que "as condições de exercício do jornalismo

13 Trata-se de um documento de final de mandato, aprovado a 20 de dezembro de 2014, designado, "Considerações apreciativas do mandato e do estado da deontologia". 
no período 2010-2014 agravaram-se com implicações no domínio ético-deontológico".

Segundo o mesmo documento, o exercício do jornalismo tem sido nos últimos anos, "impulsionado por uma orientação estratégica dos media centrada em transformar a informação em mercadoria, com o intuito de produzir espetáculo mediático e assegurar audiências e vendas. Esta perspetiva - sustenta ainda o Conselho Deontológico - conduziu gradualmente o jornalismo à situação de refém do interesse de fontes organizadas e à mercê da duvidosa qualidade de uma informação que se pretende vendável".

A esta preocupante tendência junta-se a ingerência ou intrusão de novos atores no espaço mediático, agora totalmente disponível e mais democrático. As novas possibilidades tecnológicas de comunicação trouxeram consigo um aumento exponencial de informação, a qual, todavia, está a transformar muitos órgãos de comunicação em espaços abertos à proliferação de rumores, boatos e mentiras (Silverman, 2015). No estudo que efetuou sobre jornalismo em rede, em que analisou 1.500 notícias,
Silverman (2015) conclui que o ritmo apressado e pouco verificador da parte dos jornalistas está a conduzir a profissão para práticas pouco fiáveis, ao acolher com demasiada facilidade rumores e ao promover a desinformação. O mesmo autor afirma que os jornais online, hoje, são mais uma parte do problema da desinformação, do que parte da solução, uma vez que o seu trabalho revela, entre outros aspetos, falta de tempo para pensar e refletir sobre as matérias noticiosas, com reflexos negativos para a qualidade da informação que veiculam.

Claro que vão surgindo, ao lado, projetos inspirados no slow journalism, em países como a Espanha e França (para referir exemplos não anglo-americanos), como são, entre outros, os casos das publicações online Contexto (Ctxt.es) e The Conversation (https:// theconversation.com/fr), esta última com a curiosidade de juntar (e fazer disso uma diferença assumida) estudantes universitários, académicos e jornalistas de vários países, sob o lema, "L'expertise universitaire, le flair journalistique". Assim como, no papel, e também em França, o semanário Le 1 (sai à quarta-feira) e a revista $X X I$ (trimestral e que apenas se vende em livrarias ou por assinatura) vão fazendo o seu caminho alternativo e de aposta forte na fidelização de leitores, ao ponto de ambos os títulos não aceitarem publicidade nas suas páginas. Àquelas duas publicações juntou-se recentemente uma outra revista (Revue du Crieur) que, como as anteriores, privilegia a reflexão, a análise e o jornalismo em profundidade, em detrimento da atualidade apressada e ansiosa. Podemos, ainda, acrescentar, fora do espaço europeu, os casos das revistas mensais Etiqueta Negra (Peru) e Piauí(Brasil), cujo perfil editorial escapa igualmente ao chamado mainstream e em que os géneros privilegiados são o Perfil, a Crónica e o Ensaio.

Em Portugal, o panorama não conhece projetos equivalentes, não obstante uma ou outra tentativa isolada, que acaba por não singrar nem impor-se. Em todo o caso, afigura-se-nos apropriada a referência a experiências bem sucedidas, não apenas porque elas devem servir de incentivo aos alunos e de bons exemplos para discussão em espaço de aula, mas, também, para que tenhamos o quadro 
mais completo possível sobre os múltiplos cenários e contextos em que o jornalismo hoje é exercido e a sua prática se concretiza. Só assim, aliás, entendemos que faz sentido refletir e questionarmo-nos sobre o ensino do jornalismo e arriscar algumas ideias ou propostas, tendo em vista ajustá-lo aos novos quadros e contextos em que a profissão é exercida.

\section{A Universidade como}

\section{vanguarda do jornalismo}

Colocados, portanto, diante de uma realidade que é complexa e que, na sua essência, tem estado fora da órbita de influência das universidades, que opções devem estas assumir no sentido de adequar o ensino do jornalismo às atuais exigências da profissão ou dos que procuram uma formação nessa área que, como vimos, não têm propósitos nem pressupostos coincidentes?

Até agora, a oferta tem sido ampla e diversificada, o que reflete bem a pluralidade de perspetivas e abordagens com que o seu ensino é entendido. A Walter Cronkite School of Journalism and Mass Communication, na Universidade do Arizona, por exemplo, tem uma forte componente prática apoiada por jornalistas. O curso assume entre as várias saídas profissionais, o jornalismo e as relações públicas, mas também os departamentos de comunicação das organizações. Ainda nos EUA, a Ball State University parte do pressuposto que tanto os jornalistas como os profissionais de relações públicas visam, no desempenho das suas ações e funções, captar a atenção e tocar as audiências. A diferenciação do ensino que presta reside, no entanto, no facto de fornecer cursos online. A Universidade de Boston aposta igualmente numa prática consistente, mas assume como pressuposto que o bom jornalista deve saber História, ter conhecimentos de Direito, e conhecer a ética do jornalismo. A Escola de Jornalismo do El País, que funciona numa parceria com a Universidade Autónoma de Madrid e que em 2016 celebra 30 anos de vida, oferece um "master" de dois anos em jornalismo, no último dos quais os alunos são remunerados. Pelo meio promove oficinas de jornalismo de fim de semana, dedicadas a temáticas e a géneros jornalísticos específicos.
Estes exemplos servem para mostrar a diversidade de opções que podem ser tomadas no ensino do jornalismo. Entre os casos referidos e a realidade portuguesa há, no entanto, um pormenor que faz toda a diferença: o nosso mercado, leia-se, o número de potenciais alunos é manifestamente menor, em Portugal. Donde, é crucial, em nosso entender, alargar a outros países, designadamente ao Brasil, Angola, Moçambique e Cabo Verde, onde o português é igualmente falado, o ensino do jornalismo, seja ao nível da licenciatura, seja ao nível de pós-graduações e cursos de especialização e atualização. A prática do ensino online, por videoconferência, deve ser, neste contexto, uma hipótese a analisar.

Diante de um problema concreto, como seja o ensino do jornalismo em tempos de mudança e de crise dos media, com evidentes repercussões nos jornalistas, importa perguntar: o que é que a universidade tem para propor no atual quadro de incerteza e de hegemonia do mercado e das suas lógicas? Por outras palavras, o que é que a universidade e o ensino do jornalismo podem propor de diferente, mas na 
linha dos princípios que defendem e propagam, face a um mercado que dita e impõe as regras de funcionamento e de exercício de uma profissão em nítido processo de erosão? Qual o sentido - e sustentação - no ensino, por exemplo, do jornalismo de referência, quando os seus parâmetros são cada vez menos respeitados e surgem crescentemente fragilizados? Porquê debater, analisar e insistir no ensino de um jornalismo virado para o aprofundamento das questões e respeito escrupuloso pelos princípios éticos e deontológicos, quando a prática diária nos mostra que tais preocupações não estão na linha da frente do trabalho realizado, fruto das condições em que ele é feito? ${ }^{14}$

É justamente face a estes cenários que a universidade deve propor e mostrar práticas alternativas, proporcionando aos seus alunos espaços e oportunidades para estes se realizarem através de experiências e vivências, capazes de os fazer sentir e apreender a dimensão mais autêntica

14 Em fevereiro de 2013, o Washington Post, que foi pioneiro, em 1970, quando criou a figura do Ombudsman, decidiu acabar com essa figura. e ambiciosa do exercício do jornalismo sem as condicionantes do mercado e das audiências. Ao mesmo tempo que aprofundam e testam a compatibilização de um jornalismo exigente com o cumprimento escrupuloso das regras éticas e deontológicas.

A questão não é de hoje, porquanto já Kant debatia, no seu tempo, o papel ambivalente da universidade: a busca do conhecimento pelo conhecimento e o compromisso entre a pesquisa e a sua ligação à prática. Neste contexto, entendemos que a universidade tem hoje uma responsabilidade acrescida, uma vez que já não deve circunscrever-se ao papel de ensinar o jornalismo - mas também de o praticar. Ou, no mínimo, de criar as condições para o seu exercício.

Num quadro mediático onde, pelas mais diversas razões, há todo um contingente de pessoas e de temas que não fazem parte das agendas noticiosas e não são objeto de reportagens ou de entrevistas, cabe à universidade, enquanto escola e centro de aprendizagem e de experimentação, assumir um papel alternativo, trazendo para o espaço público aquilo que a informação mainstream não é capaz de tratar ou não o faz com a profundidade que a matéria em causa exige.

Ao assumir tal prática, a universidade está, ainda, a melhorar a formação cidadã dos seus alunos, ao incentivá-los a procurar e a olhar mais atentamente as múltiplas realidades existentes nos espaços que têm de conhecer para realizarem os respetivos trabalhos jornalísticos.

Sem pôr em causa a necessidade de uma formação cultural consistente que compete à academia proporcionar, o ensino do jornalismo deve, mais do que num passado recente, apostar a sério em oficinas e na produção de trabalhos jornalísticos de qualidade e exigentes, a fim de mostrar que o modelo de jornalismo e os critérios de orientação que ensina fazem sentido e fazem falta. Mais: esta dimensão oficinal e prática deveria ser corporizada na existência de um medium feito e dirigido pelo próprio curso de jornalismo, cujo modelo, consoante os respetivos contextos e meios, poderia assumir um perfil semelhante ao de uma agência de notícias ou de um órgão multimédia. $\mathrm{O}$ projeto levado a cabo pelo curso de jornalismo da Universidade Federal de Santa Catarina 
no Brasil, onde o seu site de notícias foi o primeiro jornal online daquele estado, evoluindo, depois, para uma agência de notícias multimédia supervisionada por professores e jornalistas (Meditsch \& Frighetto, 2015), é um exemplo e a prova de que é possível ensinar, fazendo. Esta experiência só foi possível depois que os professores brasileiros conheceram, no local, o caso da Universidade da Florida (EUA), cujo curso de jornalismo "funcionava em torno de um jornal comunitário, de uma emissora de TV Educativa e de três rádios, um deles comercial. Os órgãos de comunicação eram ligados à faculdade e geridos por ela. E a produção do jornalismo era feito pelo alunos" (Meditsch \& Frighetto, 2015, p. 191).

Este exemplo de sinergias, onde sobressai a imagem de uma universidade aberta ao exterior e intimamente ligada com as comunidades envolventes, constitui uma experiência que vale a pena replicar e adaptar à realidade portuguesa. Iniciativas destas poderiam ter uma importância vital em cidades e distritos onde a comunicação social tem pouca ou nenhuma expressão, com ganhos claros para todas as partes, incluindo os cidadãos da respetiva área ou região.

O jornalismo feito segundo estes moldes seria, ainda, uma oportunidade para a universidade fomentar a participação de estudantes com outras formações, como estatística e programação, duas áreas onde a generalidade das redações está muito carenciada e cujos domínios começam a fazer a diferença: "para o jornalista que nunca vai escrever uma linha de código para uso diário, dominar o bê-a-bá da tecnologia é tão importante quanto entender o básico da economia" (Anderson et al., 2013, p. 50).

Só assim, acreditamos, será possível provar a relevância e o sentido mais profundo do que se ensina, ao mostrar como o jornalismo de qualidade e sem cedências é imprescindível à boa saúde das sociedades democráticas. Seria, ao mesmo tempo, um passo importante no sentido de por em causa as regras dominantes de um mercado que dita a forma e o conteúdo de uma parte significativa da informação que hoje se produz e veicula. A universidade, cujos princípios e parâmetros de atuação e de ensino não devem estar sujeitos nem dependentes dos gostos e influências voláteis do mercado representa, neste contexto, um papel insubstituível e de primeira grandeza no processo de renovação e reafirmação do jornalismo. Nesse sentido, a universidade deveria, ainda, ter a coragem de promover, incentivar e apoiar os alunos no lançamento e criação de projetos editoriais. Quando o investimento nos media escasseia, e o desemprego e a precariedade aumentam, a única saída para os que têm no jornalismo o seu farol e paixão é serem eles a assumir o risco do seu sonho, criando projetos novos com uma identidade própria e, porventura, com o arrojo que as empresas mais antigas e mais conservadoras não são capazes.

Num momento de claro recuo e de inegável hesitação quanto ao destino e rumo do jornalismo, deve caber a quem o ensina e problematiza, a responsabilidade de proporcionar as melhores condições para a sua aprendizagem em exercício, ao mesmo tempo que coloca os seus recursos ao serviço das comunidades em que se situa e da cidadania de que nunca se deve afastar. 


\section{Conclusão}

O exercício do jornalismo foi desde sempre alvo de críticas. O alemão Tobias Peucer já em 1690, na tese de doutoramento que apresentou na universidade de Leipzig, se referia aos constrangimentos dessa atividade em que "as notícias são relatos precipitados elaborados precipitadamente" (Peucer apud Sousa, 2004, p. 40). Hoje, porém, fruto da maior revolução tecnológica depois de Gutenberg, o jornalismo enfrenta a sua maior crise de identidade e afirmação: "as mudanças radicais trazidas pelas novas tecnologias obrigam a repensar os fundamentos do jornalismo", sustenta David Klatell (2013, p. 14), professor da Columbia Journalism School, onde é responsável pela área de estudos internacionais.

Disputando o espaço mediático com outros atores e não possuindo o protagonismo e força do passado, o jornalismo tende a inserir-se na enorme indústria de produção de conteúdos e, nesse sentido, dependente das regras de mercado, em que os critérios comerciais e de marketing se sobrepõem às decisões editoriais. "É a dissolução da profissão de jornalista num continuum de ofícios da comunicação, ilustrado no neologismo americano media-worker" (Neveu, 2005, p.119).

É neste quadro que os cursos devem intervir, não no sentido de manterem o jornalismo estático e preso a um passado que já não se revê nas múltiplas dinâmicas sociais dos nossos dias, mas para assumirem a vanguarda de algo que é uma conquista da democracia, imprescindível à boa saúde democrática das sociedades contemporâneas, não obstante enfrentar os maiores dilemas e desafios da sua história.

Ao contrário do Super-Homem que desistiu do jornalismo, a universidade jamais deve capitular.

\section{Bibliografia}

Anderson, C. W., Bell, E. \& Shirky, C. (2013). Jornalismo pós-industrial: adaptação aos novos tempos. Revista de Jornalismo ESPM, 2(5), 3089. Acedido a 6 janeiro de 2016, em http://www.espm.br/download/2012_ revista_jornalismo/Revista_de_Jornalismo_ESPM_5/files/assets/common/downloads/REVISTA_5.pdf
Bell, E. (2014). Silicon Valley and Journalism: Makeup or breakup? Acedido em 4 de novembro de 2014, em http://reutersinstitute.politics. ox.ac.uk/sites/default/files/Speech\%20\%20Silicon\%20alley\%20 $\% 26 \% 20$ Journalism\%20\%20 Make\%20up\%20or\%20Break\%20 up_Emily\%20Bell_Reuters\%20 Memorial\%20Lecture\%202014.pdf

Boczkowski, P. J. \& Mitchelstein, E. (2013). News Gap: when the information preferences of the media and the public diverge. Cambridge: MIT Press.

Chaparro, M. C. (2001). A Linguagem dos Conflitos. Coimbra: Minerva.

Deuze, M. (2008). The changing context on news work: liquid journalism and monitorial citizenship. International Journal of Communication, 2, 848-865. Acedido a 10 de dezembro de 2015, de http://ijoc.org/ojs/ index.php/ijoc/issue/view/2

Fidalgo, A. (2004). Jornalismo online segundo o modelo de Otto Groth. Acedido a 8 de janeiro, 2016, em http://www.bocc.ubi.pt/pag/fidalgo-groth-jornalismo-online.pdf

Figueira, J. (2015). O triunfo do jornalismo de comunicação ou a erosão de uma 
profissão em mudança. Estudos do século XX: Comunicação, jornalismo e espaço público na era digital, 15, 57-75.

Groth, O. (2011). O Poder Cultural Desconhecido: Fundamentos da ciência dos jornais. Petrópolis: Vozes.

Innerarity, D. (2010). O Novo Espaço Público. Lisboa: Teorema.

Jorge, T. de M. (2013). Mutação no Jornalismo: Como a notícia chega à internet. Brasília: Universidade de Brasília.

Klatell, D. (2013). Ética e imprensa. Revista de Jornalismo ESPM, edição brasileira da Columbia Journalism Review, abril/junho. São Paulo: ESPM.

Kovach, B. \& Rosenstiel, T. (2010). Blur: how to know what's true in the age of information overload. New York: Bloomsbury.
Kovach, B. \& Rosenstiel, T. (2004). Os elementos do jornalismo: o que os profissionais do jornalismo devem saber e público deve exigir. Porto: Porto Editora.

Krotz, F. (2007). Part I: Researching media internationalization: the meta-process of mediatization as a conceptual frame. Global Media \& Communication, 3, 256.

Lloyd, J. \& Toogood, L. (2015). Journalism and PR: News media and the public relations in the digital age. London: I.B. Tauris.

Macnamara, J. (2014). Journalism \& PR: Unpacking spin, stereotypes, \& media myths. New York: Peter Lang.

Marshall, L. (2003). O Jornalismo na Era da Publicidade. São Paulo: Summus.

Marquez, G. G. (1996). La Fundación de Gabo. FNPI, taller del periodismo en transformación, Acedido a 13 de janeiro de 2016, em http://www. fnpi.org/fileadmin/documentos/Actividades/Actividades_2014/informegabo.pdf

Mcchesney, R. W. \& Nichols, J. (2010). The Death and Life of American Journalism. Philadelphia: Nation Books.

Meditsch, E. \& Frighetto, M. (2015). O projeto Universidade Aberta da UFSC: uma experiência pioneira da práxis multimídia do ensino do jornalismo. Revista Brasileira de Ensino do Jornalismo: Antigas ou novas mídias: o ensino do jornalismo repaginado?, 5(17), 187-201. Acedido em 13 janeiro de 2016, em http://www.fnpj.org.br/rebej/ ojs/index.php/rebej/article/viewFile/423/258 
Neveu, E. (2005). Sociologia do Jornalismo. Porto Editora.

Patterson, T. E. (2003). Tendências do jornalismo contemporâneo: estarão as notícias leves e o jornalismo crítico a enfraquecer a democracia?. Media \& Jornalismo, 2.

Pavlik, J. V. (2014). Ubiquidade: 07 . $^{\circ}$ princípio do jornalismo na era digital. In Webjornalismo: 7 caraterísticas que marcam a diferença (pp. 159-183). Covilhã: UBI, LabCom.

Picard, R. G. (2010). Value Creation and the Future of News Organizations: Why and how journalism must change to remain relevant in the twenty-first century. Lisboa: Media XXI.

Ramonet, I. (2012). O poder mediático. In Dênis de Moraes (Org.). Por uma outra comunicação: mídia, mundialização cultural e poder (pp. 243-252). Rio de Janeiro: Record. Silverman, C. (2015). Lies, damn lies, and viral content: how news websites spread (and debunk) online rumors, unverified claims, and misinformation. Tow Center for Digital Journalism. Recuperado em fevereiro, 2015, de http://towcenter. org/wp-content/uploads/2015/02/ LiesDamnLies_Silverman_TowCenter.pdf

Singer, J. B. (2003). Who are these guys?: The online challenge to the notion of journalistic professionalism. Journalism, 4(2), 139163. Acedido em 15 de julho de 2013, de http://pt.scribd.com/ doc/64185502/Week-1-Singer-J-B-2003-Who-Are-These-Guys.http:// pt.scribd.com/doc/64185502/
Week-1-Singer-J-B-2003-Who-Are-These-Guys

Sousa, J. P. (2004). Tobias Peucer: progenitor das teorias do jornalismo. Estudos em Jornalismo e Media, 1(2), $2^{\circ}$ semestre, 31-46. Acedido a 13 de janeiro de 2016, de https:// periodicos.ufsc.br/index.php/jornalismo/article/view/2071/1813

Varela, J. (2011). Periodismo mutante. Revista Telos, 86. Acedido a 2 de março, de 2011, https://telos. fundaciontelefonica.com/DYC/ TELOS/NMEROSANTERIORES/ Nmeros80102/DetalleAnteriores_86TELOS_DOSSIERPV4/ seccion $=1268 \&$ idioma $=$ es_ES\&i$\mathrm{d}=2011012610500001 \&$ activo $=6 . \mathrm{do}$ 